\title{
Stress-Induced Reinstatement of Nicotine Preference Requires Dynorphin/Kappa Opioid Activity in the Basolateral Amygdala
}

\author{
(DStephanie K. Nygard, ${ }^{1,2}$ Nicholas J. Hourguettes, ${ }^{1}$ G Gabe G. Sobczak, ${ }^{1}$ William A. Carlezon, ${ }^{5}$ \\ and Michael R. Bruchas ${ }^{1,3,4}$ \\ ${ }^{1}$ Department of Anesthesiology, ${ }^{2}$ Department of Psychiatry, ${ }^{3}$ Washington University Pain Center, and ${ }^{4}$ Department of Neuroscience, Washington \\ University School of Medicine, St. Louis, Missouri 63110; and 5Department of Psychiatry, Harvard Medical School, McLean Hospital, Belmont, \\ Massachusetts 02478
}

The dynorphin (DYN)/kappa-opioid receptor (KOR) system plays a conserved role in stress-induced reinstatement of drug seeking for prototypical substances of abuse. Due to nicotine's high propensity for stress-induced relapse, we hypothesized that stress would induce reinstatement of nicotine seeking-like behavior in a KOR-dependent manner. Using a conditioned place preference (CPP) reinstatement procedure in mice, we show that both foot-shock stress and the pharmacological stressor yohimbine $(2 \mathrm{mg} / \mathrm{kg}$, i.p.) induce reinstatement of nicotine CPP in a norbinaltorphimine (norBNI, a KOR antagonist)-sensitive manner, indicating that KOR activity is necessary for stress-induced nicotine CPP reinstatement. After reinstatement testing, we visualized robust c-fos expression in the basolateral amygdala (BLA), which was reduced in mice pretreated with norBNI. We then used several distinct but complementary approaches of locally disrupting BLA KOR activity to assess the role of KORs and KOR-coupled intracellular signaling cascades on reinstatement of nicotine CPP. norBNI injected locally into the BLA prevented yohimbine-induced nicotine CPP reinstatement without affecting CPP acquisition. Similarly, selective deletion of BLA KORs in KOR conditional knock-out mice prevented foot-shock-induced CPP reinstatement. Together, these findings strongly implicate BLA KORs in stress-induced nicotine seeking-like behavior. In addition, we found that chemogenetic activation of $\mathrm{G} \alpha \mathrm{i}$ signaling within $\mathrm{CaMKII} \alpha$ BLA neurons was sufficient to induce nicotine CPP reinstatement, identifying an anatomically specific intracellular mechanism by which stress leads to reinstatement. Considered together, our findings suggest that activation of the DYN/KOR system and G $\alpha$ i signaling within the BLA is both necessary and sufficient to produce reinstatement of nicotine preference.

Key words: basolateral amygdala; conditioned place preference; kappa opioid receptors; nicotine; reinstatement; stress

\section{Significance Statement}

Considering the major impact of nicotine use on human health, understanding the mechanisms by which stress triggers reinstatement of drug-seeking behaviors is particularly pertinent to nicotine. The dynorphin (DYN)/kappa-opioid receptor (KOR) system has been implicated in stress-induced reinstatement of drug seeking for other commonly abused drugs. However, the specific role, brain region, and mechanisms that this system plays in reinstatement of nicotine seeking has not been characterized. Here, we report region-specific engagement of the DYN/KOR system and subsequent activation of inhibitory $\left(G_{\mathrm{i}}\right.$-linked) intracellular signaling pathways within the basolateral amygdala during stress-induced reinstatement of nicotine preference. We show that the $\mathrm{DYN} / \mathrm{KOR}$ system is necessary to produce this behavioral state. This work may provide novel insight for the development of therapeutic approaches to prevent stress-related nicotine relapse.

\section{Introduction}

Nicotine use is the leading cause of preventable death, being responsible for about one in every five deaths in the United States, and has strikingly high rates of relapse (Lerman et al., 2014).

Received March 22, 2016; revised Aug. 2, 2016; accepted Aug. 5, 2016.

Author contributions: S.K.N. and M.R.B. designed research;S.K.N., N.J.H., and G.G.S. performed research; W.A.C. contributed unpublished reagents/analytic tools; S.K.N., N.J.H., and G.G.S. analyzed data; S.K.N., W.A.C., and M.R.B. wrote the paper.
Relapse to smoking occurs in $>90 \%$ of abstinent smokers and stress is the most common reason reported for relapse (al'Absi et al., 2007). In laboratory studies, both foot shock and the pharmacological stressor yohimbine have been shown to reinstate drug- 
seeking behaviors reliably for prototypical substances of abuse such as cocaine, opiates, and nicotine (Sinha et al., 2011; Mantsch et al., 2016). Yohimbine is an $\alpha$-2 adrenergic receptor antagonist that produces responses of stress and dysphoria in humans and rodents and there is accumulating evidence that the dynorphin (DYN)/kappa-opioid receptor (KOR) system plays a role in these effects (Koob, 2013; Grella et al., 2014; Lalanne et al., 2014; Zhou and Leri, 2016). Conditioned place preference (CPP) procedures are especially useful to study nicotine reinstatement due to the importance of contextual cues in the nicotine addiction process (Subramaniyan and Dani, 2015) and because cue-induced craving is a strong predictor of relapse to nicotine use in humans (Droungas et al., 1995; Janes et al., 2010). In addition, place preference procedures are increasingly being used in human drug abuse studies, providing more validity for CPP rodent models (Napier et al., 2013; Astur et al., 2016). Redila and Chavkin (2008), show that stress-induced reinstatement of cocaine CPP is blocked by the KOR antagonist norbinaltorphimine (norBNI). Forced swim stress has been shown to reinstate nicotine CPP in mice (Jackson et al., 2013; Titomanlio et al., 2014) and can be prevented by KOR antagonism (Jackson et al., 2013), suggesting that KOR activation through endogenous DYN released during stress is necessary for reinstatement. We recently showed that activating the KOR system with a KOR agonist is sufficient to induce reinstatement of both cocaine and nicotine CPP (AlHasani et al., 2013a; Al-Hasani et al., 2013b). However, how the KOR system plays a role in nicotine reinstatement is less understood. Here, we tested the hypothesis that foot-shock stress and the pharmacological stressor yohimbine would both produce endogenous DYN release and activate specific regional KORs and induce reinstatement of nicotine CPP.

The amygdala is known to be involved in reward-context/cue associations, specifically functioning to assign importance to reward associated cues and to continually update the value of those cues (Murray, 2007; Koob, 2009). The basolateral amygdala (BLA) is KOR rich (Mansour et al., 1988) and activation of DYN/ KOR systems in the BLA has anxiogenic effects (Bruchas et al., 2009; Knoll et al., 2011; Crowley et al., 2016). KOR function in the BLA and associated circuits is activated by stress and plays a role in stress-induced dysphoria (Land et al., 2008). Nicotine CPP has been shown to be potentiated by stress via the BLA without affecting other anxiety-related behaviors (Smith et al., 2012). Activation of KORs with the KOR agonist U50-488 decreases synaptic transmission and LTP in the BLA and inhibits glutamatergic activity of BLA to bed nucleus of stria terminalis (BNST) projection neurons to mediate anxiogenic behavior (Huge et al., 2009; Crowley et al., 2016). Considering the effects of BLA KOR activation on anxiety-like behavior and on cellular activity within the BLA, we hypothesized that KOR signaling in the BLA may play a role in stress-induced nicotine CPP reinstatement. Specifically, we hypothesized that stress-induced activation of the endogenous DYN/KOR system within the BLA would be necessary for stress to reinstate nicotine CPP.

Here, we report that DYN/KOR activity in the BLA is a key mediator of stress-induced nicotine reinstatement. We show that activation of $\mathrm{G} \alpha \mathrm{i}$ signaling within the BLA is sufficient for nico-

Within the past 2 years, W.A.C. has served as a consultant for Cerecor. The remaining authors declare no competing financial interests.

Correspondence should be addressed to Michael R. Bruchas, Ph.D., Washington University, School of Medicine, 660 South Euclid Ave, Box 8054, St. Louis, M0 63110. E-mail: bruchasm@wustl.edu.

DOl:10.1523/JNEUROSCI.0953-16.2016

Copyright $\odot 2016$ the authors $\quad 0270-6474 / 16 / 369938-12 \$ 15.00 / 0$ tine CPP reinstatement and that BLA KORs are necessary for this effect. Our results provide new insights on how KORs transduce the effects of stress and add to the scientific basis for considering KOR antagonists as potential therapies for nicotine use disorders.

\section{Materials and Methods}

\section{Animals}

Male WT C57BL/6 mice, $\mathrm{KOR}^{-1-}$, $\mathrm{DYN}^{-1-}$, KOR conditional $\mathrm{KO}$ (cKO) (Van't Veer et al., 2013a), and KOR cKO ${ }^{\text {tdTomato }}$ (a line generated by crossing KOR cKO mice with Ai9tdTomato reporter mice) mice with a C57BL6 background weighing 25-30 g (8-10 weeks old) at the time of behavioral testing were used. Surgery was performed on 6- to 7-week-old mice to ensure appropriate age at time of CPP testing. Mice were housed 3-5 per cage and maintained in a holding room adjacent to the behavioral testing room for at least $7 \mathrm{~d}$ before the start of testing. Mice had ad libitum access to food and water and were maintained on a $12 \mathrm{~h}$ light/dark schedule (lights on at 7:00 A.M. and off at 7:00 P.M.). All procedures were approved by the Animal Care and Use Committee of Washington University and were in accordance with National Institutes of Health guidelines.

\section{Genotyping}

Three- to 4-week-old mice were tail clipped to obtain DNA samples for genotyping. PCR screening was used with the following primers: $\mathrm{KOR}^{-1-}$ (5'-GTC TAA TTG TCT TTT GGC CAC TGC AGA TGG-3' and: $3^{\prime}$-TAG ATG TTG GTT GCG GTC TTC ATC TTC GTG-5' ) yield a 450 bp product in WT mice and (5'-TGC TCC TGC CGA GAA AGT ATC CAT CAT GGC-3' and $3^{\prime}$-CGC CAA GCT CTT CAG CAA TAT CAC GGG TAG-5') which yields a $380 \mathrm{PCR}$ product in $\mathrm{KO}$ mice. The following primers were used to genotype DYN ${ }^{-1-}$ mice: $5^{\prime}$-DYN (Mouse) $30 \mathrm{bp}$ : ATC CTT TCA GAT TTG CTC CCT GGA GTG CCA; 3'-DYN (Mouse) 30 bp: CAT AGC GCT TCT GGT TGT CCC ACT TCA GCT (500 bp PCR product); 5' Neo (MGC) 38030 bp: TGC TCC TGC CGA GAA AGT ATC CAT CAT GGC; 3' Neo (MGC) 38030 bp: CGC CAA GCT CTT CAG CAA TAT CAC GGG TAG (380 bp PCR product). KOR cKO mice: (5'-TATTGCTGAC CTATCGTGAAC-3' ', 5' -GAGCTACTGTTTTCATACCATTTA- ${ }^{\prime}$, and 5' TTGAGGCTACTAGTTTCCAAAG-3'), with PCR products of 399 bp for WT DNA, $459 \mathrm{bp}$ for unrecombined DNA, and $563 \mathrm{bp}$ for the knock-out (Van't Veer et al., 2013a). Ai9 was confirmed with the following primers: Ai9 WT FWD (oIMR9020) 20 bp: AAG GGA GCT GCA GTG GAG TA; Ai9 WT REV (oIMR9021) 20 bp: CCG AAA ATC TGT GGG AAG TC; Ai9 Mutant FWD (oIMR9105) 19 bp: CTG TTC CTG TAC GGC ATG G; Ai9 Mutant REV (oIMR9103) 20 bp: GGC ATT AAA GCA GCG TAT CC. with PCR products of $275 \mathrm{bp}$ for WT and $150 \mathrm{bp}$ for tdTomato positive.

\section{Drug administration}

(-)-Nicotine hydrogen tartrate salt (Sigma-Aldrich, N5260) $(0.5 \mathrm{mg} / \mathrm{kg}$, corrected for the weight of the tartrate salt) was dissolved in saline and injected subcutaneously. Yohimbine hydrochloride $(2 \mathrm{mg} / \mathrm{kg}$ ) (SigmaAldrich, Y3125) was dissolved in sterile water and injected intraperitoneally. Norbinaltorphimine (norBNI) dihydrochloride (log no. 13335-66A) was injected intraperitoneally $(10 \mathrm{mg} / \mathrm{kg})$ or intracranially $(2.5 \mu \mathrm{g} / 1 \mu \mathrm{l})$, dissolved in saline or ACSF, respectively, as the vehicle. Clozapine $N$-oxide (CNO, $1 \mathrm{mg} / \mathrm{kg}$, i.p.) was purchased from Enzo Life Sciences, BML-N51050025). CNO was made in $0.5 \%$ DMSO in saline.

\section{Handling/habituation}

Mice were transported to the CPP behavior testing room and handled once per day for at least $7 \mathrm{~d}$ before behavioral testing. Each mouse was scruffed, its belly rubbed, and head gently poked to habituate them to subcutaneous injections. Prior handling is important in inducing nicotine CPP in mice (Grabus et al., 2006).

\section{$C P P$}

We used a modified three-chamber CPP apparatus consisting of two square boxes $(27 \mathrm{~cm} \times 27 \mathrm{~cm})$ that served as the conditioning chambers separated by a small center area that served as the passage way $(5 \mathrm{~cm}$ wide $\times 8 \mathrm{~cm}$ long) between boxes, as described previously (Land et al., 2008; Bruchas et al., 2011; Al-Hasani et al., 2013a; Al-Hasani et al., 2013b). Boxes had $2.5 \mathrm{~cm}$ black-and-white vertical stripes or horizontal 
Table 1. Average time spent in drug-paired side during each test for all groups

\begin{tabular}{|c|c|c|c|c|c|}
\hline \multirow[b]{2}{*}{ Experiment } & \multicolumn{5}{|l|}{ Time (s) } \\
\hline & Pre & Post & Extinction & Reinstate & Prime \\
\hline Saline-only (foot shock) & $471.1(11.79)$ & $482.6(27.90)$ & $518.7(27.89)$ & $523.7(20.34)$ & $489.4(36.57)$ \\
\hline Foot shock + saline & $449.2(10.30)$ & $596.8(19.51)$ & $466.1(17.79)$ & $600.6(26.96)$ & $637.1(73.91)$ \\
\hline Foot shock + norBNI & $438.2(19.10)$ & $586.2(21.76)$ & $480.9(20.73)$ & $471.7(21.02)$ & $579.2(93.22)$ \\
\hline Saline-only (yohimbine) & $548.2(65.21)$ & $441.4(56.13)$ & $505.9(52.09)$ & $532.3(51.26)$ & $\mathrm{N} / \mathrm{A}$ \\
\hline Yohimbine + saline & $407.6(18.33)$ & $573.4(24.71)$ & $489.9(25.14)$ & $688.9(47.47)$ & $\mathrm{N} / \mathrm{A}$ \\
\hline Yohimbine + norBNI & $417.2(23.49)$ & $594.8(19.04)$ & $524.1(24.27)$ & $530.1(32.79)$ & $\mathrm{N} / \mathrm{A}$ \\
\hline WT & $461.0(27.46)$ & $558.2(47.76)$ & $382.4(33.40)$ & $520.1(38.20)$ & 784.8 (16.41) \\
\hline $\mathrm{KOR}^{-1-}+$ yohimbine & $482.0(15.34)$ & $594.7(12.51)$ & $470.4(40.52)$ & $497.3(32.82)$ & $825.5(62.42)$ \\
\hline DYN $^{-1-}+$ yohimbine & $396.4(21.32)$ & $541.5(41.63)$ & $431.8(31.89)$ & $443.6(33.48)$ & $590.0(83.81)$ \\
\hline mCitrine & $445.8(49.5)$ & $613.0(50.92)$ & $585.1(65.44)$ & $547.9(67.88)$ & $\mathrm{N} / \mathrm{A}$ \\
\hline $\mathrm{Gi}$ & $461.5(8.76)$ & $611.8(36.37)$ & $564.2(28.55)$ & $684.3(59.74)$ & $\mathrm{N} / \mathrm{A}$ \\
\hline BLA ACSF + yohimbine & $423.5(24.42)$ & $581.2(26.21)$ & $487.4(29.00)$ & $614.8(27.59)$ & $610.6(104.1)$ \\
\hline BLA norBNI + yohimbine & $451.9(14.76)$ & $568.2(13.60)$ & $433.8(24.86)$ & $487.2(54.88)$ & $531.5(63.85)$ \\
\hline KORcKO/BLA/GFP/foot shock & $450.2(20.22)$ & $541.8(20.76)$ & $512.3(27.74)$ & $653.9(49.18)$ & $738.5(82.66)$ \\
\hline KORcKO BLA/Cre/foot shock & $458.8(17.84)$ & $576.9(17.52)$ & $509.4(26.98)$ & $511.1(32.54)$ & $670.4(63.18)$ \\
\hline
\end{tabular}

Shown are the mean time (SEM) in seconds spent in the drug paired side of the (PP apparatus during each stage of behavioral testing (pre, post, extinction, reinstate, prime) for each group in each experiment in the study.

N/A, Not applicable.

stripes and floors were covered with $500 \mathrm{ml}$ of bedding on each side. The floor of the center area was smooth Plexiglas.

Mice were transported to the CPP behavior testing room and handled once per day for at least $7 \mathrm{~d}$ before behavioral testing. Mice were then conditioned using a semibiased and counterbalanced CPP/reinstatement protocol adapted from previous studies (Brielmaier et al., 2008; AlHasani et al., 2013a; Al-Hasani et al., 2013b; Ngolab et al., 2015). On day one, mice were pretested for an initial bias to the conditioning apparatus and allowed to explore all three regions of the box drug-free for $20 \mathrm{~min}$. Mice that spent $>150 \mathrm{~s}$ in one side of the apparatus $(\sim 10-15 \%)$ were nicotine paired with the least preferred side. Remaining mice were paired in a counterbalanced fashion. Mice that spent $>300 \mathrm{~s}$ on one side during the pretest were excluded due to potential side bias. However, overall, our chambers do not appear to be biased, with mice $(n=73)$ spending an average of $510.80 \mathrm{~s}$ (SEM 30.15) in the horizontal side and $487.50 \mathrm{~s}$ (SEM 35.02 ) in the vertical side before conditioning, with no statistically significant difference between the groups. Conditioning occurred over the following $2 \mathrm{~d}$ in which mice received a subcutaneous injection of saline in the morning and immediately confined to one side of the CPP box for 20 $\min$. In the afternoon, at least $4 \mathrm{~h}$ after the morning conditioning session, mice received an injection of nicotine $(0.5 \mathrm{mg} / \mathrm{kg}$, s.c.) and were immediately confined to the opposite side for $20 \mathrm{~min}$ This dose of nicotine has been optimized for CPP in our laboratory (Al-Hasani et al., 2013a; AlHasani et al., 2013b) and has been shown to be effective in inducing CPP in mice (Grabus et al., 2006b; Matta et al., 2007; Jackson et al., 2013). Control (vehicle-injected) mice received saline injections during both A.M. and P.M. conditioning sessions. The following day, mice were tested for a preference for the nicotine-paired side following the same procedure as the pretest. Preference scores were calculated by subtracting time spent in the drug-paired side during the pretest from time spent in the drug-paired side during the posttest. Mice were considered conditioned if their CPP score was $\geq 10 \%$ of their total conditioning time during the posttest.

\section{Extinction and reinstatement}

As described previously for prototypical drugs of abuse (Al-Hasani et al., 2013a; Al-Hasani et al., 2013b; Portugal et al., 2014), we used a modified extinction procedure in which mice that expressed a CPP for the nicotine side were then extinguished for $2 \mathrm{~d}$ following the same procedure as the conditioning sessions, but instead of nicotine in the P.M. sessions, mice received saline injections in both A.M. and P.M. conditioning sessions. Extinction scores were calculated by subtracting the time spent in the drug-paired side during the posttest from time spent in the drug-paired side during the extinction test (Table 1). Mice with extinction scores that were $<10 \%$ of total conditioning time were considered to be extinguished (95\% of those tested) and were then tested for reinstatement with either yohimbine ( $2 \mathrm{mg} / \mathrm{kg}$, i.p) $5 \mathrm{~min}$ before reinstatement testing (as reported in Mantsch et al., 2010) or intermittent, unavoidable footshock stress for $15 \mathrm{~min}$, which was reported previously to engage the KOR system (Redila and Chavkin, 2008). For systemic norBNI experiments, mice were initially split into two groups. One group was conditioned with nicotine and another group was treated with saline during both A.M. and P.M. conditioning sessions to serve as non-drug-treated controls. After initial CPP testing, nicotine-conditioned mice were split into two groups with equal preference scores (yohimbine or foot shock + saline and yohimbine or foot shock + norBNI). After the extinction test and the morning of the reinstatement test (18 and $4 \mathrm{~h}$ before reinstatement), mice received an injection of saline or norBNI (10 mg/kg, i.p.) depending on group, as described previously (two injections of norBNI or saline) (McLaughlin et al., 2003; Bruchas et al., 2007; Land et al., 2008; Smith et al., 2012; Melief et al., 2011).

For yohimbine reinstatement, yohimbine $(2 \mathrm{mg} / \mathrm{kg}$ ) was injected intraperitoneally and mice were placed back in their home cages. Control (vehicle) mice were injected with saline and placed back in their home cage. After $5 \mathrm{~min}$, mice were placed in the center of the CPP apparatus and tested for reinstatement as described previously (Land et al., 2008; Mantsch et al., 2010; Bruchas et al., 2011; Jackson et al., 2013). For footshock stress reinstatement, $20 \mathrm{~min}$ before reinstatement testing, mice were shuttled from the CPP testing room to an intentionally different adjacent room with the shock apparatus (Med Associates, MED-PC, RRID:SCR_012156), put in the shock box for $5 \mathrm{~min}$ of habituation, and then were exposed to $15 \mathrm{~min}$ of random shocks $(0.8 \mathrm{~mA})$ that lasted $0.5 \mathrm{~s}$ each with an intershock interval ranging from 10 to $70 \mathrm{~s}$ with a mean of $40 \mathrm{~s}$. Vehicle-treated controls were put in shock apparatus for $20 \mathrm{~min}$ before reinstatement testing, but did not receive shocks. Mice were then shuttled back to the CPP testing room and immediately tested for nicotine CPP reinstatement. Our shock protocol has been shown to reinstate cocaine-CPP in mice (Song et al., 2007; Redila and Chavkin, 2008) and nicotine self-administration in rats (Buczek et al., 1999). For DREADD experiments, CNO $(1 \mathrm{mg} / \mathrm{kg})$ was injected intraperitoneally and mice were placed back in their home cages for $30 \mathrm{~min}$ before being placed into $\mathrm{CPP}$ apparatus for reinstatement testing. Given the timing effects of KOR agonist on potentiation and reinstatement, this time point was chosen to produce a maximally robust effect (McLaughlin et al., 2003; Smith et al., 2012; Al-Hasani et al., 2013a; Al-Hasani et al., 2013b).

\section{Stereotaxic microinjections}

Local pharmacology. For local KOR antagonist experiments, mice were injected bilaterally (BLA coordinates $\mathrm{ML} \pm 3.1, \mathrm{AP}-1.8$, DV -5 ; Bruchas et al., 2009; Smith et al., 2012) with the KOR antagonist norBNI (2.5 $\mu \mathrm{g} / 1 \mu \mathrm{l}$ ) or vehicle (ACSF) (see Fig. $4 A, B$ ). The injection volume was 500 $\mathrm{nl} / \mathrm{side}$ and was injected at a rate of $100 \mathrm{nl} / \mathrm{min}$. The syringe was left in place for $10 \mathrm{~min}$ after the injection to allow for drug diffusion. Due to the long-lasting properties of the KOR antagonist norBNI (Bruchas et al., 
2007), we were able to give mice $7 \mathrm{~d}$ to recover before the start of behavioral testing.

Viral injections. For KOR conditional KO studies, KOR floxed (KOR cKO; see Fig. 5A, left) mice were bilaterally injected into the BLA with either AAV5-Cre-GFP $\left(8.1 \times 10^{12} \mathrm{vg} / \mathrm{ml}\right)$ or the control virus AAV5GFP, both purchased from UNC Viral Vector Core (see Fig. 5D-F). Then, $400 \mathrm{nl}$ of virus was injected on each side at a rate of $100 \mathrm{nl} / \mathrm{min}$. The syringe was left in place for an additional $8 \mathrm{~min}$ before retracting to avoid capillary effects, for a total injection time of 12 min per side. To confirm conditional deletion of KORs from KOR cKO mice and to visualize successful cre recombination, KOR cKO mice were also crossed with the cre-dependent Ai9 tdTomato reporter mouse line (Madisen et al., 2010), resulting in a new $\mathrm{KOR} \mathrm{cKO}^{\text {tdTomato }}$ mouse line. When $\mathrm{KOR} \mathrm{cKO}^{\text {tdTomato }}$ mice are injected with AAV-cre-GFP, KOR is conditionally deleted and tdTomato/GFP are simultaneously expressed in infected cells (see Fig. 5A-C) to confirm robust, virally induced cre recombinase activity.

For DREADD experiments, AAV5-CaMKII $\alpha$-HA-hM4D $\left(G_{\mathrm{i}}\right)$-IRESmCitrine $\left(2.7 \times 10^{12} \mathrm{VM} / \mathrm{ml}\right)$ or AAV5-CaMKII $\alpha$-mCitrine (control virus), purchased from UNC Vector Core was injected bilaterally into the BLA (BLA coordinates $\mathrm{ML} \pm 3.1, \mathrm{AP}-1.8, \mathrm{DV}-5$ ) at a volume of $300 \mathrm{nl}$ over $3 \mathrm{~min}$ per side. The syringe was left in place for $10 \mathrm{~min}$ total to allow for viral diffusion. Mice were given 3 weeks for viral expression before behavioral testing (see Fig. $6 A-C$ ).

\section{Immunohistochemistry}

Mice were transcardially perfused with ice-cold $4 \%$ paraformaldehyde 90 min after yohimbine-induced reinstatement and tissue was stained to visualize $\mathrm{c}$-fos expression. Mice that had surgery before testing were perfused to confirm viral expression in the BLA (see Figs. $5 E, F ; 6 A-C$ ). Mice with no reporter gene expression on both sides of the brain or misplaced expression were excluded from behavioral analysis.

After perfusion, brains were stored in 30\% sucrose solution until sectioning $(30 \mu \mathrm{m})$ and staining. Briefly, as described previously (Al-Hasani et al., 2013b; McCall et al., 2015), for c-fos IHC, sections (6-8 sections per well, $2 \mathrm{ml}$ volume for all washes and incubations) were washed 3 times in PBS and then blocked with blocking buffer (PBS with 5\% normal goat serum and $0.3 \%$ Triton $\mathrm{X}-100$ ) for $1 \mathrm{~h}$ at room temperature. Sections were then incubated overnight at $4^{\circ} \mathrm{C}$ in blocking buffer containing the primary antibody for c-fos (c-fos rabbit polyclonal IgG; Santa Cruz Biotechnology, sc-52 RRID:AB_2106783,1:500). After $24 \mathrm{~h}$ of primary antibody incubation, sections were washed 3 times in PBS before secondary antibody incubation (Alexa Fluor 594 goat-anti-rabbit IgG; Thermo Fisher Scientific, R37117 RRID:AB_2556545, 1:1000) for $2 \mathrm{~h}$ at room temperature. Sections were then washed 3 more times in PBS and 2 times in PB before Nissl staining (Neurotrace 435/455 Blue Fluorescent Nissl stain; ZcomThermo Fisher Scientific, N21479). Sections were incubated for $1 \mathrm{~h}$ in $2 \mathrm{ml}$ PBS with $5 \mu \mathrm{l}$ of Neurotrace and then washed 3 more times in PBS and 3 more times in PB. Tissues from mice that were perfused just to confirm viral expression were not stained for c-fos, so staining began with the Neurotrace step. Free-floating sections were mounted in $0.1 \mathrm{~PB}$ and coverslips were applied over mounted sections with Vectashield Hard Set mounting medium (Vector Laboratories, H-1400 RRID:AB_2336787). Slides were imaged on both epifluorescent and confocal microscopes. For quantification, images were acquired with the same gain and exposure time across brain regions and treatment groups.

\section{Cell quantification}

C-fos + cells were quantified as described previously (Al-Hasani et al., 2013b; Kim et al., 2013; McCall et al., 2015). Briefly, images from 3 consecutive sections from $n=6$ mice per group were taken on a epifluorescent microscope. Images were broken down into individual channels (Neurotrace: blue channel; c-fos: red channel) and analyzed separately. ImageJ (RRID:SCR_003070) particle analysis was used to count the number of c-fos-positive cells relative to the number of Neurotracepositive cells within a given region. Images were overlaid and the percentage of colabeled cells was reported. Counting was performed blinded to treatment. The percentage of Ai9 tdTomato and GFP coexpression in the BLAs of KORcKO ${ }^{\text {tdTomato }}$ mice injected with AAV5-cre-GFP was done the same way; however, the individual channels were different (Neurotrace: blue channel-not shown; GFP: green channel; and TdTomato: red channel). The percentage of GFP/TdTomato-colabled cells is presented as the percentage of Neurotrace-positive cells within a given region.

\section{Data analysis and statistics}

Two-way (on time/stage) repeated-measures (RM)-ANOVAs were used to compare differences in preference scores and locomotor responses (separately) between groups during each stage of testing. In cases in which groups were unequal for each stage of testing (because groups were split to move on to nicotine-prime reinstatement testing or perfused after reinstatement testing), prime data were analyzed separately with one-way RM-ANOVA or paired $t$ test as appropriate. One-way ANOVAs were used to analyze c-fos quantification data. Significant ANOVAs were followed by Bonferonni post hoc comparisons and statistically significant differences were determined at $p<$ 0.05 . All data and statistical analysis was performed using Prism version 6 or 7 (GraphPad, RRID:SCR_002798).

\section{Results}

\section{KOR activation is necessary for foot-shock stress-induced nicotine reinstatement}

To determine whether stress would reinstate a previously extinguished CPP for nicotine, we exposed mice to $15 \mathrm{~min}$ of unavoidable intermittent foot shock before reinstatement testing (see Fig. $1 \mathrm{~A}$ for experimental timeline and foot-shock protocol). We found that foot shock reliably reinstated nicotine CPP and that this effect is blocked by pretreatment with norBNI ( $10 \mathrm{mg} / \mathrm{kg}$, i.p; $n=12-16$ per group, two-way RM-ANOVA, $F_{(2,40)}=16.84, p<0.001$; Fig. 1C). Post hoc comparisons showed a significant increase in reinstatement scores in the foot shock + saline group compared with saline-only controls and stressed mice pretreated with norBNI (all comparisons $p<$ 0.001; see Table 1 for comparison of time spent in the drug-paired side during each stage of testing). Furthermore, norBNI did not have an effect on nicotine-primed reinstatement in nicotine-conditioned mice $\left(n=6-9\right.$ per group, one-way ANOVA, $F_{(2,18)}=9.25, p=$ 0.002 ), consistent with previous reports (Schindler et al., 2010; Jackson et al., 2013). Post hoc comparisons showed that a nicotine prime injection reinstated nicotine conditioned mice regardless of norBNI pretreatment (saline-only compared with foot shock + saline, $p=$ 0.002; saline-only compared with foot shock + norBNI, $p=0.037$; Fig. 1C). As expected, nicotine decreased locomotor behavior during conditioning sessions in both groups of nicotine-conditioned mice compared with saline-treated controls $(n=12-16$ per group, twoway RM-ANOVA, $F_{(2,40)}=11.29, p<0.001$; Fig. $\left.1 D\right)$. No differences were seen in locomotor behavior during drug-free testing (see Fig. $1 A, B$ for timeline and representative tracks of distance traveled during each testing time point). However, during the nicotine prime test, nicotine treatment again decreased locomotor responses compared with saline controls only in mice from the foot shock + saline group (two-way RM-ANOVA, $F_{(2,40)}=23.16, p<0.001$; multiplecomparisons $p=0.0004)$. norBNI treatment before stress reinstatement ( $24 \mathrm{~h}$ earlier) attenuated nicotine's hypolocomotive effects during the prime test because there was no significant difference between this group and saline controls $(p=0.08$; Fig. $1 E)$. These data suggest that KOR activity is necessary for stress-induced reinstatement, but not prime reinstatement of nicotine CPP, and that the effect is specific to stress and not prime-induced reinstatement.

\section{KOR activation is necessary for yohimbine-induced nicotine reinstatement}

To determine whether the widely used pharmacological stressor yohimbine (Lê et al., 2005; Banna et al., 2010; Mantsch et al., 2010; Mantsch et al., 2016) would also induce nicotine CPP rein- 
A
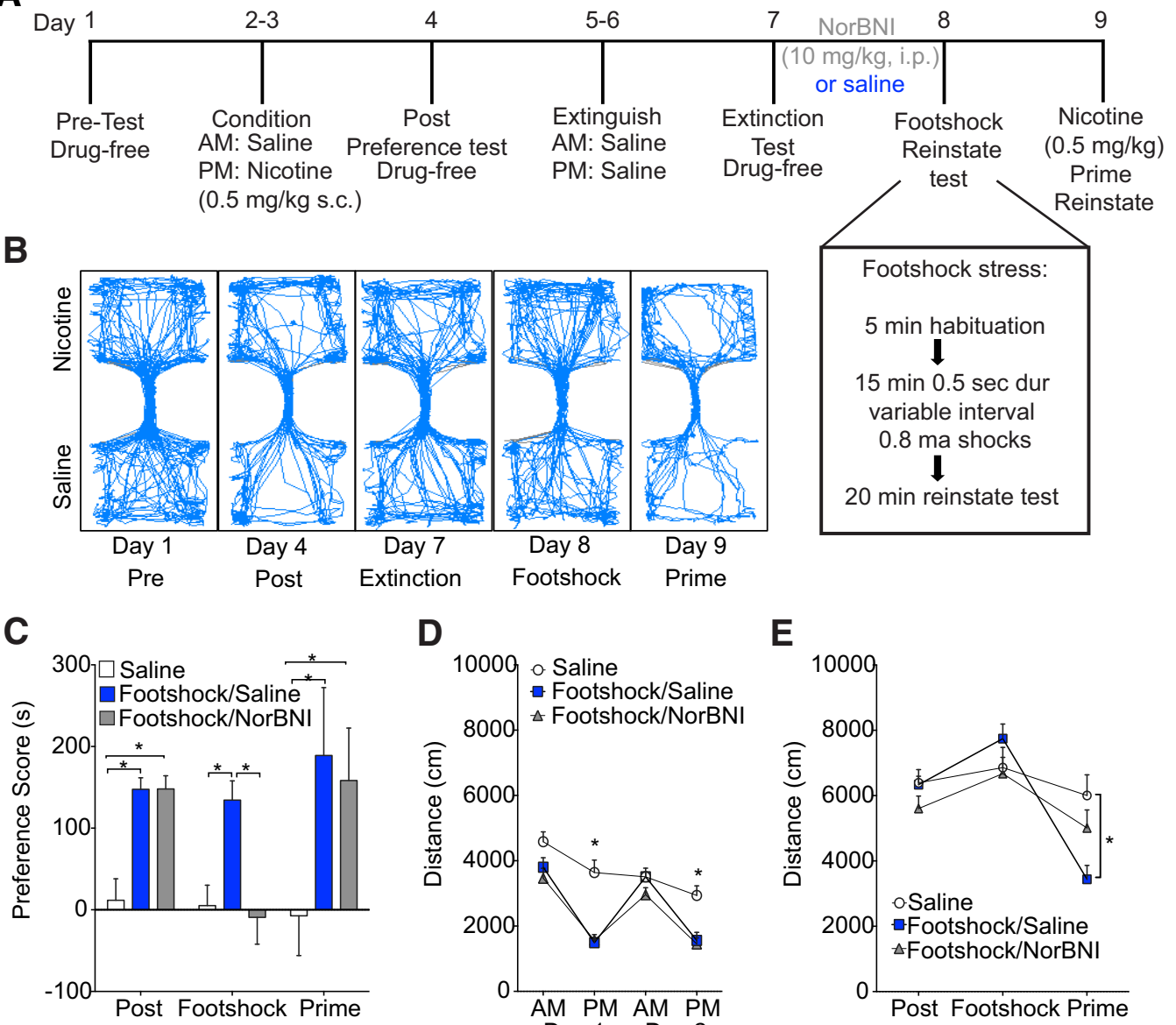

D

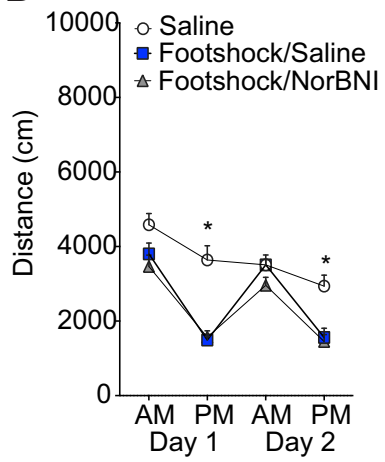

E

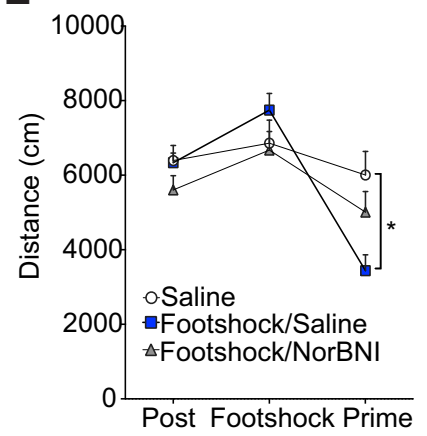

Figure 1. KOR activation is necessary for foot-shock stress-induced nicotine reinstatement. $\boldsymbol{A}$, Timeline of behavioral testing schedule and protocol. $\boldsymbol{B}$, Representative traces of locomotor behavior (distance traveled) during each stage of testing (pre, post, extinction, foot shock reinstatement, prime). C, Foot-shock stress before testing (day 8 ) reinstates nicotine (PP in a norBNI (10 mg/kg, i.p.)-sensitive manner. D, Locomotor responses are decreased during nicotine treatment (days 2 and 4, P.M. session) compared with saline-treated controls. $E$, Neither foot-shock stress nor norBNI pretreatment changes locomotor behavior during reinstatement testing. $n=12-16$ per group, ${ }^{*} p<0.05$.

statement, we injected yohimbine ( $2 \mathrm{mg} / \mathrm{kg}$, i.p.) $5 \mathrm{~min}$ before reinstatement testing (see Fig. $2 A$ for timeline). Similar to foot shock, yohimbine reinstated nicotine CPP in a norBNI $(10 \mathrm{mg} /$ kg, i.p.)-sensitive manner $(n=8-10$ per group, two-way RM-ANOVA, $F_{(2,26)}=18.08, p<0.0001$; Fig. $\left.2 B\right)$. Consistent with our foot-shock results and previous reports (Itzhak and Martin, 1999), nicotine significantly decreased locomotor responses during P.M. conditioning sessions compared with saline controls (main effect treatment $F_{(2,26)}=3.97, p=0.04$; Fig. $2 C$ ). Locomotor responses during preference and reinstatement tests were unaltered by pretreatment with norBNI (main effect treatment $F_{(2,26)}=0.13, p=0.88$; Fig. $\left.2 D\right)$.

To corroborate our pharmacological studies and determine whether the DYN/KOR system is necessary for stress-induced reinstatement and if genetic deletion of KOR or DYN affects reinstatement, we tested additional groups with of either the KOR gene $\left(\mathrm{KOR}^{-1-}\right)$ or pre-pro-DYN $\left(\mathrm{DYN}^{-/-}\right)$knock-out mice against their littermate controls. In these groups, we found that KOR and DYN KO mice displayed CPP scores comparable to WT control groups (no significant differences in CPP scores during postpreference test). However, neither $\mathrm{KOR}^{-1-}$ or $\mathrm{DYN}^{-1-}$ mice showed reinstatement of nicotine CPP after yohimbine, whereas a priming injection of nicotine induced reinstatement in both groups (two-way RM-ANOVA, main effect treatment, $n=$
5-9 per group, $F_{(2,18)}=5.08, p=0.02$; post hoc comparisons only showed significant differences during reinstatement: $\mathrm{KOR}^{-1-}$ compared with WT, $p=0.02 ; \mathrm{DYN}^{-1-}$ compared with WT, $p=$ 0.05; Fig. 2E, Table 1 ). $\mathrm{KOR}^{-1-}$ and $\mathrm{DYN}^{-1-}$ mice showed locomotor responses to nicotine during conditioning similar to WT controls (main effect treatment not significant $F_{(2,18)}=1.81$, $p=0.18$; Fig. $2 F)$. Similarly, no significant differences were detected in distance traveled during preference and reinstatement testing (main effect treatment not significant $F_{(2,18)}=0.18, p=$ 0.84; Fig. 2G). Together, these results suggest that, like foot-shock stress, the DYN/KOR system is engaged by the pharmacological stressor yohimbine and that both KOR and pre-pro-DYN play a critical role in the reinstatement of nicotine CPP.

\section{KOR activation is necessary for increased BLA c-fos expression after nicotine CPP reinstatement}

To investigate the regional effects of stress and yohimbine on neuronal activity, we performed immunohistochemistry (IHC) to visualize c-fos, the commonly used immediate to early gene marker of recent cellular activity (Minatohara et al., 2015). To determine whether yohimbine-induced reinstatement produced changes in neural activity throughout the brain, we perfused mice $90 \mathrm{~min}$ after the reinstatement test ( $2 \mathrm{~h}$ after yohimbine injection) and used IHC to visualize c-fos expression (Fig. 3A) in regions 
A

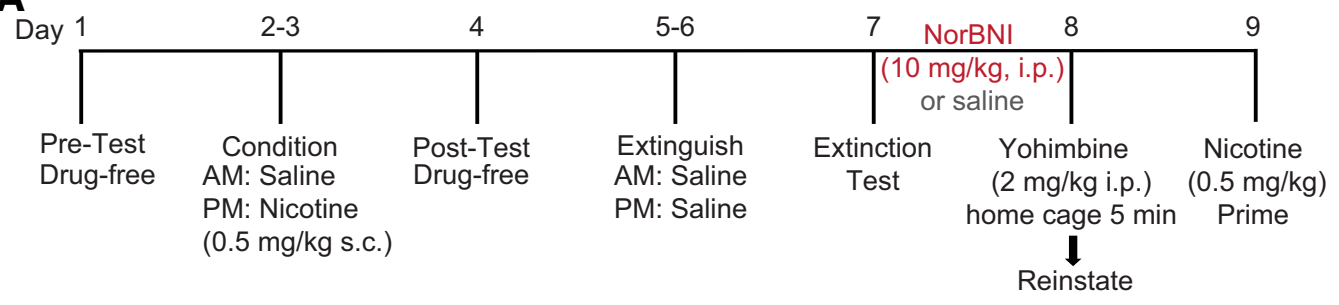

B

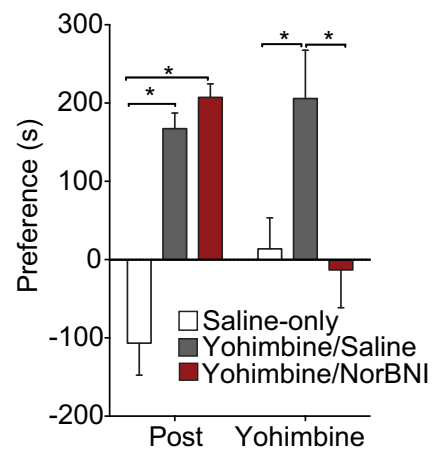

E

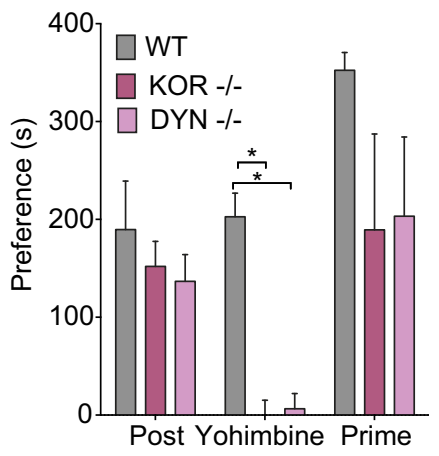

C

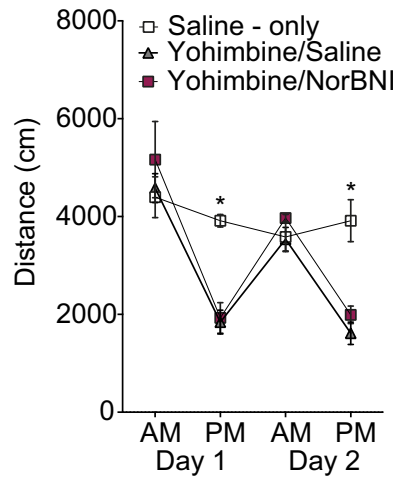

F

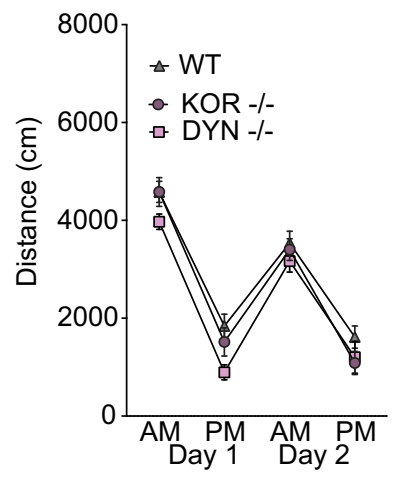

D

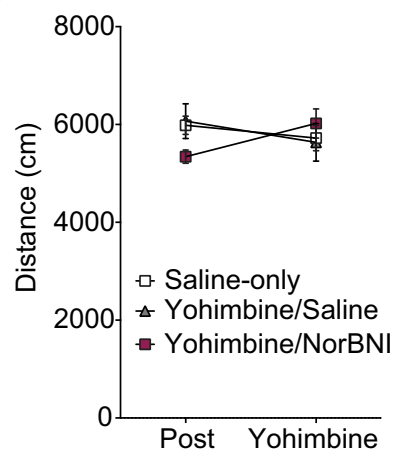

G

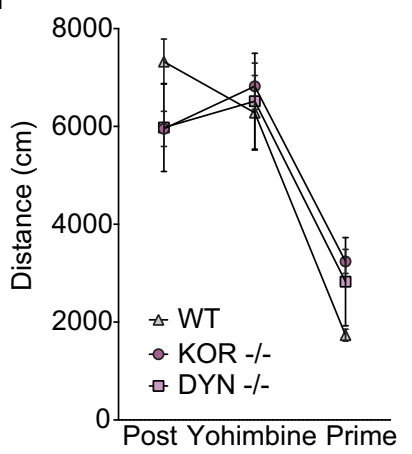

Figure 2. KOR activation is necessary for yohimbine-induced nicotine reinstatement. $A$, Experimental timeline for behavioral testing and protocols. $B$, Yohimbine $(2 \mathrm{mg} / \mathrm{kg}$, i.p.) $5 \mathrm{~min}$ before testing reinstates nicotine CPP in a norBNI (10 mg/kg, i.p.)-sensitive manner. C, Nicotine decreases locomotor behavior compared with saline controls. D, Locomotor responses are unchanged during CPP testing by pretreatment with norBNI. $E, K^{-1} \mathrm{R}^{-1-}$ and $\mathrm{DYN}^{-1-}$ show similar CPP scores as WT controls during the posttest and nicotine prime reinstatement test, but do not reinstate after yohimbine treatment. $\boldsymbol{F}, \mathrm{KOR}^{-1-}$ and DYN ${ }^{-1-}$ mice show similar decrease in locomotion after nicotine treatment as seen in WT controls. $\boldsymbol{G}_{,} \mathrm{KOR}^{-1-}$ and DYN ${ }^{-1-}$ mice do not differ from WT controls in distance traveled during CPP or reinstatement tests. For $\boldsymbol{B}-\boldsymbol{D}, n=8-10$ per group; for $\boldsymbol{E}-\boldsymbol{G}, n=5-9$ per group; ${ }^{*} p<0.05$.

shown previously to be KOR sensitive (Land et al., 2008; Bruchas et al., 2011; Li et al., 2012; Crowley et al., 2016). We found that the percentage of c-fos+-stained cells in the BLA was significantly greater in yohimbine-treated mice than in saline controls (Fig. $3 B, n=5-6$ mice per group, one-way ANOVA, $F_{(2,13)}=32.87$, $p<0.0001)$. However, corresponding to our behavioral results, mice pretreated with norBNI before yohimbine reinstatement had significantly fewer $c$-fos + cells in the BLA compared with yohimbine/saline-treated mice (post hoc comparisons all $p<$ $0.01)$. No changes were seen in the total number of Nissl-stained cells between any of the groups $\left(F_{(2,13)}=0.102, p=0.90\right.$; Fig. $3 C$ for representative images). In other brain regions that we visualized, we failed to detect norBNI-sensitive changes that paralleled our behavioral results (Table 2 ). The percentage of $c$-fos + cells in the central amygdala (CeA) was increased compared with saline controls after yohimbine-treatment regardless of norBNI pretreatment $\left(n=3-6\right.$ mice per group, one-way ANOVA, $F_{(2,12)}=$ $9.39, p=0.003)$. No changes were seen between any groups in the percentage of c-fos + cells in the BNST $(n=3-5$ mice per group; one-way ANOVA, $\left.F_{(2,10)}=3.78, p=0.07\right)$. The percentage of
DRN c-fos + cells was also increased after yohimbine einstatement $\left(n=2-6\right.$ mice per group; one-way ANOVA, $F_{(2,11)}=$ 54.27, $p=0.001$ ). Post hoc comparisons showed that, although both yohimbine-treated groups of mice had significantly more c-fos + cells than saline controls, the increase was significantly greater in mice pretreated with norBNI compared with yohimbine/saline-treated mice (all $p<0.05$ ). Together, these data support the conclusion that c-fos activity in the BLA is altered in a norBNI-sensitive manner after yohimbine einstatement, suggesting that DYN/KOR system is regulating this system in response to yohimbine exposure. The changes in BLA c-fos expression that we observed corresponded to the changes that we saw in behavior, indicating that KOR signaling within the BLA may be important in mediating this behavior.

\section{DYN/KOR activity within the BLA is required for} stress-induced nicotine $\mathrm{CPP}$ reinstatement

To test the hypothesis that functional KOR signaling in the BLA is required for yohimbine-induced reinstatement, we locally injected the long-lasting KOR antagonist norBNI (Bruchas et al., 
A

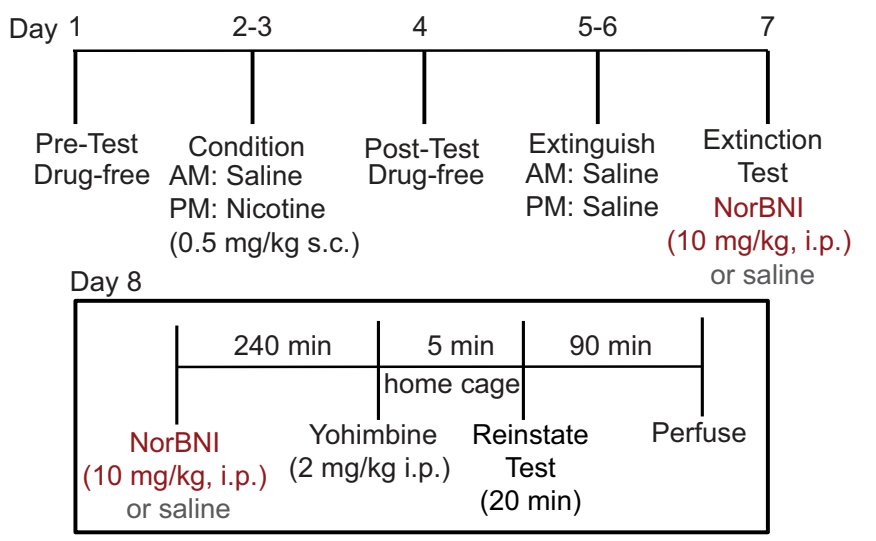

C

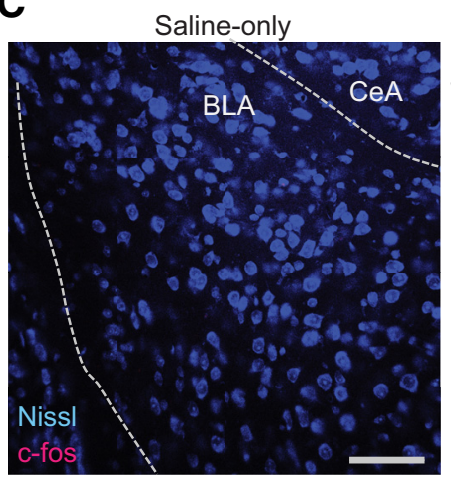

Yohimbine/Saline

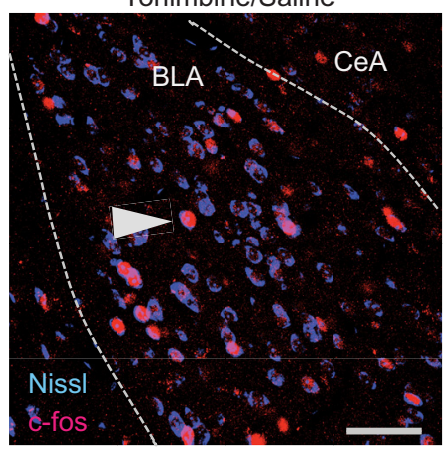

B

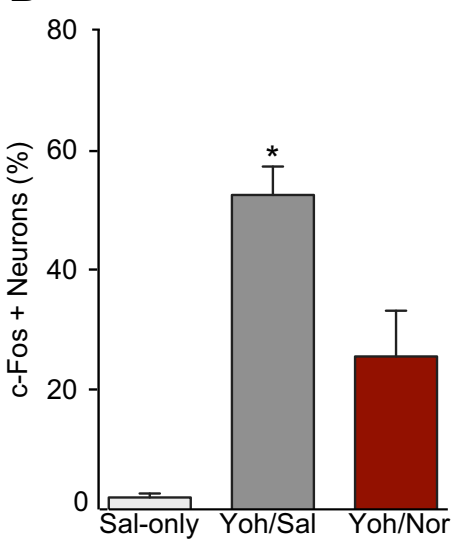

Yohimbine/NorBNI

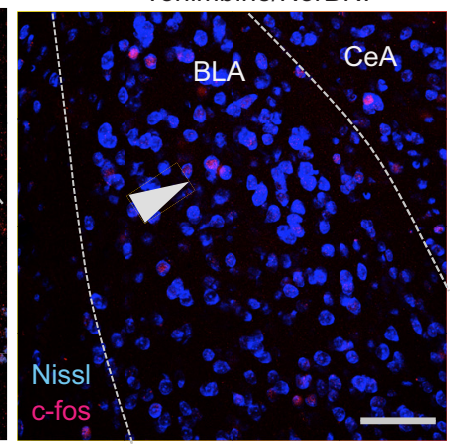

Figure 3. KOR activation is necessary for increased BLA c-fos expression after yohimbine-induced reinstatement. $A$, Timeline of behavioral events/treatment before perfusions after yohimbineinduced reinstatement to visualize $c$-fos expression within the BLA. $\boldsymbol{B}$, Percentage of neurons with both c-fos + and Nissl stain is increased compared with saline controls or mice pretreated with norBNI $\left(n=6\right.$ mice per group; $\left.{ }^{*} p<0.05\right)$, of c-fos + cells shown in $\boldsymbol{C}$. C, Representative confocal images ( $20 \times$ ) of BLA c-fos expression from each group quantified in $\boldsymbol{B}$. Nissl (blue) and c-fos (red) staining. White arrow points to c-fos + - and Nissl +-labeled cell. Scale bars, $50 \mu \mathrm{m}$.

Table 2. Mean percentage of $\mathrm{c}-$ fos $^{+} / \mathrm{Niss}^{+}{ }^{+}$-colabeled cells in the BLA, CeA, BNST, and DRN after yohimbine-induced nicotine CPP reinstatement

\begin{tabular}{llll}
\hline & \multicolumn{3}{l}{ Treatment Group } \\
\cline { 2 - 4 } Region & Saline-only & Yohimbine/saline & Yohimbine/norBNI \\
\hline BLA & $2.01(0.66)$ & $52.45(4.75)^{a}$ & $25.53(7.62)^{a, b}$ \\
CeA & $0(0)$ & $40.71(3.36)^{a}$ & $31.96(7.58)^{a}$ \\
BNST & $0(0)$ & $46.33(7.39)$ & $37.05(14.99)$ \\
DRN & $6.77(1.37)$ & $34.96(2.89)^{a}$ & $74.08(4.50)^{a, b}$ \\
\hline
\end{tabular}

Shown are the mean and (SEM) percent of $c$-fos ${ }^{+}$cells in the BLA, central amygdala (CeA), bed nucleus of the stria terminalis (BNST), and dorsal raphe nucleus (DRN) after yohimbine reinstatement for each group of mice.

${ }^{a}$ Significantly different from saline-only group.

${ }^{b}$ Significantly different from yohimbine/saline group.

2007; Melief et al., 2011; Al-Hasani et al., 2015) bilaterally into the BLA before the start of behavioral testing. KOR antagonism in the BLA (see Fig. $4 A, B$ for a timeline for injections and behavior) before behavioral testing prevents yohimbine-induced nicotine $\mathrm{CPP}$ reinstatement without affecting nicotine $\mathrm{CPP}$ acquisition or prime reinstatement $\left(n=8-12\right.$ per group, $F_{(2,48)}=7.61, p=$ 0.01 ; post hoc showed only yohimbine reinstatement scores differed significantly between the two groups $p=0.0007$; Fig. $4 C, D)$. Nicotine significantly decreased locomotion during P.M. conditioning in both groups of mice compared with A.M. locomotor responses (main effect conditioning session $F_{(3,75)}=$ 102.2, $p<0.0001$; post hoc comparisons $p=0.01$ both groups). However, mice locally injected with norBNI in the BLA showed significantly less nicotine-induced hypolocomotion during P.M. conditioning sessions compared with vehicle-treated controls (main effect of treatment $F_{(1,25)}=8.18, p=0.008$; Fig. $4 E$ ). No differences were seen in locomotor behavior during CPP or reinstatement testing $\left(F_{(1,18)}=1.89, p=0.18\right.$; Fig. $\left.4 F\right)$.

To test the hypothesis that KOR expression within the BLA is necessary for stress-induced reinstatement, we used a recently developed mouse line to delete KORs selectively within certain cell types or regions (Van't Veer et al., 2013a) and crossed it with the Ai9 tdTomato reporter mouse line to generate a new KOR $\mathrm{cKO}^{\text {tdTomato }}$ mouse line (Fig. $5 A, B$ ). Colabeling of GFP cells and TdTomato cells was observed in $80.56 \%$ of BLA cells, indicating that these cells had successful cre recombination and KOR deletion (Fig. 5C). Conditional deletion of BLA KORs in KOR cKO mice significantly prevented foot-shock stress-induced nicotine CPP reinstatement ( $n=6-9$ per group, two-way RM-ANOVA, $\left.F_{(2,26)}=4.32, p=0.024\right)$. Post hoc tests confirmed that the only significant difference between groups was during the reinstatement test, in which KOR cKO mice injected with AAV-cre-GFP had significantly lower reinstatement scores than AAV-GFPinjected controls $(p=0.011$; Fig. $5 G)$. No differences in locomotor behavior were seen between groups during conditioning $\left(F_{(1,16)}=0.002, p=0.97\right.$; Fig. $\left.5 H\right)$ or preference/reinstatement testing $\left(F_{(1,16)}=0.95, p=0.34\right.$; Fig. $\left.5 I\right)$. Together, these data demonstrate that BLA KORs are necessary for yohimbine and foot-shock stress-induced reinstatement, but not for acquisition of the initial association or subsequent nicotine-primed reinstatement, indicating that BLA KORs are critical mediators of stress-induced nicotine reinstatement. In addition, the localized viral expression shown in Figure 5, E and F, helps to demonstrate 
that the effect of local norBNI antagonism is not due to an off-target effect at other receptors in other regions.

Chemogenetic activation of $\mathrm{G} \alpha \mathrm{I}$ signaling in the BLA is sufficient to induce reinstatement of nicotine $\mathrm{CPP}$

Our prior report suggested that systemic injection of the KOR agonist U50,488 was sufficient to reinstate nicotine $\mathrm{CPP}$, but the regional effect was not defined (Al-Hasani et al., 2013a). In addition, recent reports indicate a critical role of KORs in the BLA in generating anxiogenic behavior and showed that their actions on excitatory cells in the BLA are critical for producing this negative affective state (Bruchas et al., 2009; Crowley et al., 2016). Furthermore, KORs are well known to couple to $\mathrm{G} \alpha \mathrm{i}$ signaling pathways to mediate their effects on neurotransmitter release (Al-Hasani and Bruchas, 2011). Therefore, to determine whether G $\alpha$ i signaling within BLA excitatory cells plays a role in stress-induced reinstatement of nicotine CPP, we virally injected AAV5CaMKIIa-hM4D $\left(G_{\mathrm{i}}\right)$-mCitrine DREADD (Rei et al., 2015; Roth, 2016) into the BLA (Fig. $6 A$ for timeline). Activation of G $\alpha$ i signaling within BLA CaMKII $\alpha$ neurons (Fig. $6 B, C$ for injection diagram, confocal images of viral expression and illustrations showing spread of viral expression) with CNO 30 min before reinstatement testing, induced reinstatement to nicotine CPP in DREADD-injected mice compared with mice injected with control virus $(n=9$ $\operatorname{hM} 4 \mathrm{D}\left(G_{\mathrm{i}}\right)$ mice and $n=10$ mCitrine controls, two-way RM-ANOVA, $F_{(1,17)}=$ $16.09, p=0.0009$; Fig. $6 D)$. A two-way RM-ANOVA revealed that, although $\operatorname{hM} 4 \mathrm{D}\left(G_{\mathrm{i}}\right)$ mice were significantly less active during the $\mathrm{CNO}$ reinstatement test than during the nicotine CPP posttest, locomotor responses did not differ between $\mathrm{hM} 4 \mathrm{D}\left(G_{\mathrm{i}}\right)$ and control mice during the CPP posttest or reinstatement test $\left(F_{(1,17)}=12.39\right.$, $p=0.003$; Fig. $6 E$ ) during the test. As a nonbehavioral confirmation of DREADD activation by $\mathrm{CNO}$, we looked at cfos expression after $\mathrm{CNO}$ reinstatement and saw no costaining of cfos and $\mathrm{mCitrine}$ in the BLA. However, there was c-fos expressed in the CeA of the same section, confirming that the lack of $\mathrm{c}$-fos in the BLA was due to CNO activation of the DREADDs (Fig. 6B). Together, these data suggest that inhibition of CaMKII $\alpha$ neurons through G $\alpha$ i activation after nicotine conditioning and extinction is sufficient to induce reinstatement of nicotine CPP and suggest an anatomically specific intracellular mechanism by which stress can lead to reinstatement of nicotine preference.

\section{Discussion}

The principal findings reported here are as follows: (1) both yohimbine and foot-shock stress reliably reinstate nicotine seeking-like behavior in a CPP model in mice in a DYN/KORdependent manner; (2) the role of KOR in reinstatement is specific to stress because nicotine-prime reinstatement was unaffected by either systemic KOR antagonism or global knock-out of DYN/KOR; (3) activation of G $\alpha$ is signaling in the
BLA is sufficient to induce nicotine reinstatement; and finally (4) BLA KORs play a key role in mediating stress, but not prime-induced nicotine CPP reinstatement. These findings indicate that BLA KORs play a critical role in stress-induced nicotine reinstatement by establishing that elevated signaling via $G_{\mathrm{i}}$-coupled pathways is sufficient to produce this behavior. Together, our data suggest that, during stress, KOR inhibitory signaling within the BLA may serve to change behavioral responses to environmental stimuli such as those previously associated with the rewarding effects of nicotine.

Jackson et al. (2013) found that systemic treatment with norBNI blocks forced swim-stress-induced nicotine CPP reinstatement. Here, we extend this initial report and now show that the DYN/KOR system within the BLA is necessary stress-induced nicotine reinstatement. We extend the results of Jackson et al. (2013) by showing that two additional stressors (yohimbine and foot shock) reliably reinstate CPP for nicotine in mice. This KOR effect is specific to stress because norBNI did not block nicotineprimed reinstatement in WT mice. In addition, we report that KOR and DYN KO mice show similar locomotor responses to nicotine and condition similarly to WT controls, but genetic disruption of the KOR or DYN system results in blockade of stress-induced nicotine CPP reinstatement. Although slightly more variable than WT controls, KOR and DYN KO mice still show nicotine-primed reinstatement. Therefore, the effects of DYN/KOR system disrup- 
A

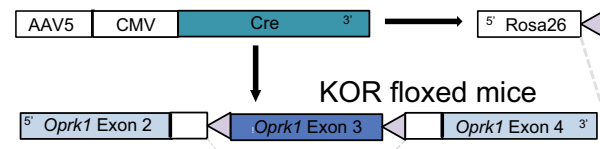

FloxP

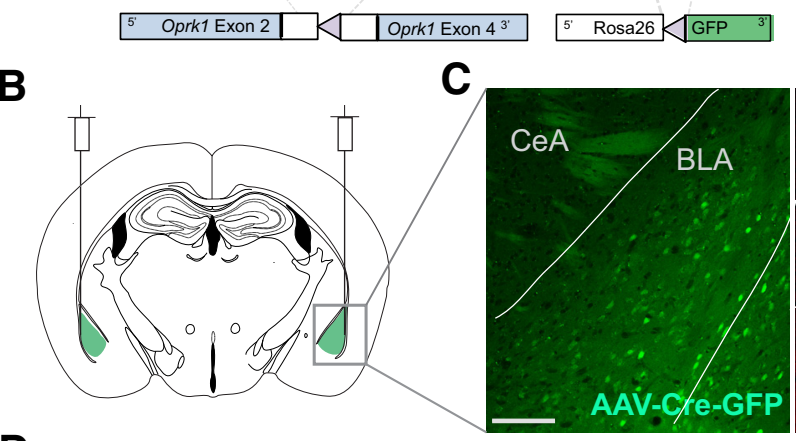

Ai9 mice

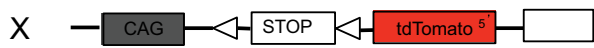

D

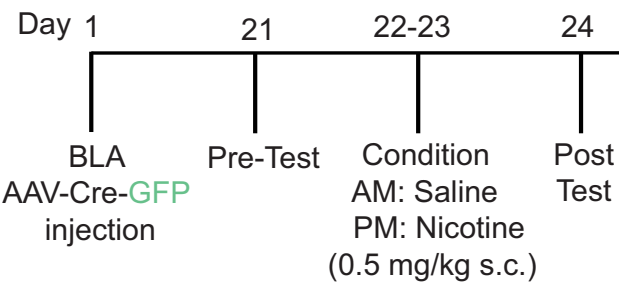

E

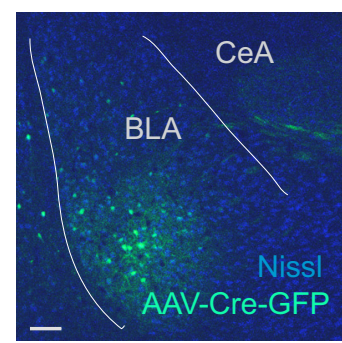

G

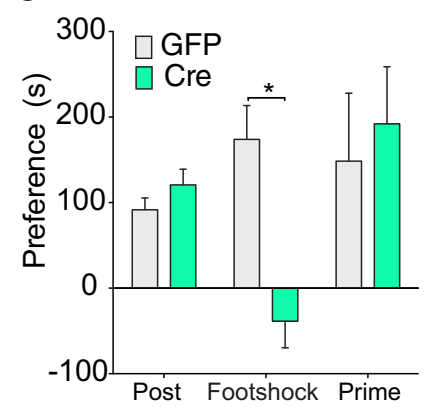

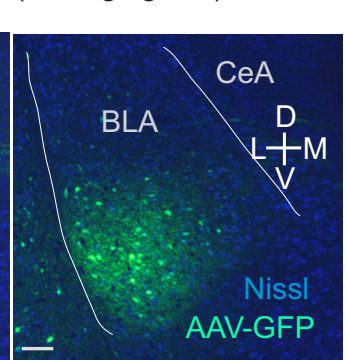

H
F

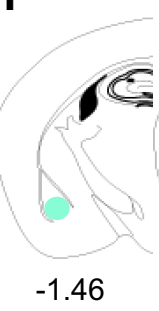

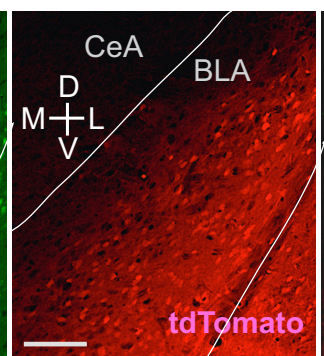

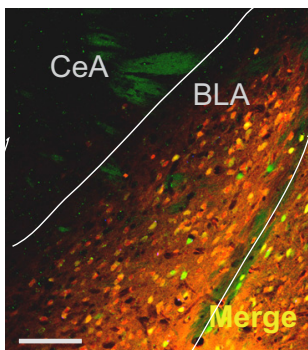

28

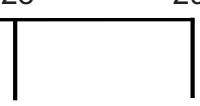

Extinguish AM: Saline PM: Saline

27

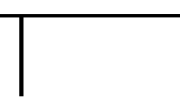

Extinction Footshock Test Reinstate 20 min

Nicotine $(0.5 \mathrm{mg} / \mathrm{kg})$ Prime Reinstate

29

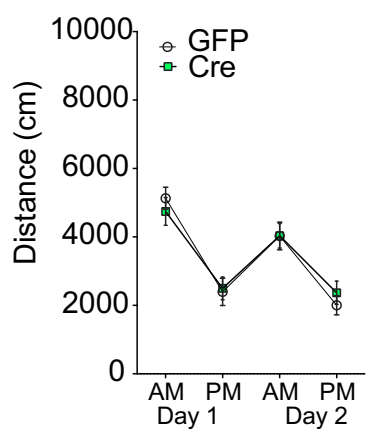

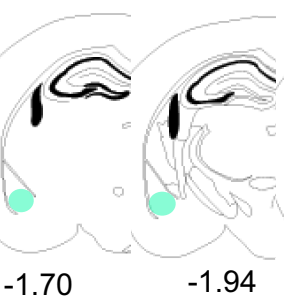

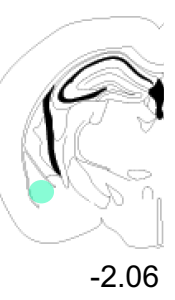

Figure 5. KORs in the BLA are necessary for foot-shock stress-induced nicotine CPP reinstatement. $A$, Diagram of cre-induced conditional knock-out of KORs in KOR floxed mice (KOR cKO) and generation of KOR cKO ${ }^{\text {tdTomato }}$ mouse line from the cross betweem KOR cKO $\times$ Aig-tdTomato. Cre-recombinase packaged into an adeno-associated virus with a GFP tag, when infects cells with floxed gene, conditionally cuts out exon 4 from the KOR gene, preventing it from being transcribed and simultaneously labels the cell with GFP. B, Diagram of viral injections into BLA of KOR cKO mice. C, Confocal images (20X) of AAV5-cre-GFP (left, green) expressed in the BLA of a KOR cKO ${ }^{\text {tdTomato }}$ mouse, cre-induced tdTomato expression (middle, red), and a merged image of the two showing that GFP + cells colabel with tdTomato + cells in the BLA, confirming the recognition of cre in floxed cells. Scale bars, $50 \mu \mathrm{m}$. D, Timeline of BLA viral injections and behavioral testing. E, Confocal (10X) of AAV5-cre-GFP (left) and AAV5-GFP (right) expression in the BLA 6 weeks after injection. Staining: GFP (green) and NissI (blue). Scale bars, $50 \mu \mathrm{m}$. F, Diagram with marks indicating viral spread in mice included in behavioral dataset. G, Selective deletion of KORs from the BLA in KOR cKO mice attenuates foot-shock stress-induced nicotine CPP reinstatement without changing CPP acquisition or prime-induced reinstatement. $\boldsymbol{H}$, No differences were seen in locomotor activity locomotor response to nicotine during conditioning. $I$, No changes in activity were seen during any testing stage. $n=6-9$ per group, ${ }^{*} p<0.05$.

tion are likely not mediated by nonspecific effects on learning or memory processes, consistent with previous reports for the KOR system in cocaine reinstatement (Land et al., 2008; Redila and Chavkin, 2008; Schindler et al., 2010; Bruchas et al., 2011). Rather, this system is activated during stress and may potentially be increasing the valence of cues previously associated with nicotine.

As a pharmacological stressor, yohimbine has generated considerable discussion and debate. Recently, Chen et al. (2015) found that 
the ability of yohimbine to reinstate operant behavior was dependent on the presence of a discrete cue after responding regardless of whether the cue was paired with a reward. Our results increase the understanding of the similarities between the mechanisms of yohimbine and stress. For example, if yohimbine acts by increasing reward-cue valence, then this may also be the mechanism by which stress reinstates drug seeking. Previous reports have in fact suggested that stress modifies the salience of cues and can thus likewise regulate behavioral responding (Schindler et al., 2010). Our results raise the possibility that this may also underlie our observations here, although this hypothesis requires further investigation. If yohimbine acts by increasing the salience of cues rather than inducing a stressful experience, our results show that the DYN/KOR system plays a role in this increased valence of cue-associations within the BLA, which in the case of nicotine CPP, leads to reinstatement. This may provide evidence that the role of DYN/KOR in both yohimbine and foot-shock stress-induced reinstatement of nicotine CPP likely involves an interaction with the cholinergic, noradrenergic, and corticotropin-releasing factor (CRF) systems (Kang-Park et al., 2015; Bashiri et al., 2016), which are critical in nicotine-seeking behaviors (Yamada and Bruijnzeel, 2011; Picciotto and Mineur, 2014). However, it is still possible that yohimbine and foot-shock stress may use different neural circuits to cause nicotine reinstatement. Future studies that fully characterize relationships among discrete cues and nicotine seeking and selfadministration behaviors, as well as a complete neural circuit analysis for DYN/KOR, are needed in future studies to resolve these outstanding questions.

We report that KOR activity in the BLA is a key mediator of stress-induced nicotine reinstatement. Furthermore, local antagonism or selective deletion of KORs in the BLA was sufficient to block stress-induced nicotine CPP reinstatement. Again, this effect is stress specific because these manipulations did not affect nicotine prime reinstatement. Systemic yohimbine treatment has been shown to increase neuronal activity and extracellular norepinephrine levels within the BLA (Buffalari and Grace, 2009). Consistent with this previous work, we show increased expression of c-fos, a marker of recent cellular activity, in the BLA after yohimbine-induced reinstatement that was attenuated in mice pretreated with norBNI, indicating the necessity of DYN/KOR activity during reinstatement testing to induce reinstatement. Together, our results show a potential mechanism by which modulation of BLA KOR-coupled intracellular signaling cascades during stress can result in nicotine CPP reinstatement. A potential explanation for our results is that we may be inducing an anxiety-like state similar to that produced by KOR activation (Bruchas et al., 2009) and stress (Kim et al., 2005). The neural adaptations that take place within the BLA (and associated circuits) during stress can change the behavioral response to a nicotine-associated context, thus inducing nicotine reinstate- ment. However, this hypothesis requires thorough manipulations of BLA signaling pathways and behavioral experiments.

Inhibition of excitatory signaling within the BLA through G $\alpha$ i activation plays a role in the regulation of synaptic plasticity and LTP induction in the BLA (Li and Rainnie, 2014). In our study, G $\alpha$ i DREADD activation was also sufficient to induce nicotine CPP reinstatement. This is consistent with a recent report showing that activation of G $\alpha$ i DREADDs in the BLA reduces stressinduced impairments in learning and memory tasks (Rei et al., 2015) and is consistent with a prior report that showed systemic $\mathrm{KOR}$ activation is sufficient to reinstate nicotine CPP (Al-Hasani et al., 2013a). However, some studies contradict this result and show that optogenetic or pharmacological inhibition of BLA neurons promotes reinstatement to drug seeking and rewardrelated behaviors (Lalumiere, 2014; Sciascia et al., 2015). These studies used optogenetics to inhibit terminals from specific projections originating in the BLA, including the prelimbic cortex and nucleus accumbens core (Britt et al., 2012; Stefanik and Kalivas, 2013), and, given the recent evidence for heterogeneity of BLA projection neurons (Namburi et al., 2015; Crowley et al., 2016), helps to explain these differences. It has also been shown that activation of BLA terminals in the CeA, a projection often implicated in reinstatement of drug seeking and CPP (Mantsch et al., 2016), decrease anxiety-like behaviors, whereas inhibition of this projection has an anxiogenic effect (Tye et al., 2011). In ad- 
dition, a recent report showed that optogenetic activation of BLA neurons projecting to the BNST decreases anxiety-like behavior, but that KOR activation blocks this anxiolytic effect and inhibits BLA glutamate transmission within this projection (Crowley et al., 2016). Future work may help to establish whether KORs within this BLA-BNST circuit play a role in nicotine CPP reinstatement. Although we are not yet able to address the issue of cell type with respect to our pharmacologic and viral manipulations within the BLA, our results provide a foundation for future studies to build from when looking at the role of BLA KOR circuitry. Further, our DREADD CaMKII $\alpha$ data, as well as the recent report from Crowley et al. (2016), suggest that excitatory neurons in the BLA are a likely mediator.

Here, we demonstrate region specific engagement of the DYN/KOR system within the BLA during stress-induced reinstatement of nicotine preference. These findings suggest that BLA KORs play a critical role in stress-induced nicotine seeking by establishing that elevated signaling via $G_{\mathrm{i}}$-coupled pathways is sufficient to produce behaviors in mice thought to reflect the persistence of nicotine addiction in humans. This work may provide novel insights for the development of therapeutic approaches to prevent stress-related nicotine relapse. Future studies will attempt to further dissect this BLA circuitry to identify celltype specificity of these KOR circuits involved with stressinduced reinstatement of nicotine CPP and where and how endogenous DYN tone (cell types) is engaged by stress-induced nicotine interactions. These studies also further support recent efforts for using KOR antagonists as therapeutics for relapse to drug seeking.

\section{References}

al'Absi M (2007) Stress and addiction: Biological and psychosocial mechanisms. London: Elsevier Academic Press.

Al-Hasani R, Bruchas MR (2011) Molecular mechanisms of opioid receptor-dependent signaling and behavior. Anesthesiology 115:13631381. CrossRef Medline

Al-Hasani R, McCall JG, Bruchas MR (2013a) Exposure to chronic mild stress prevents kappa opioid-mediated reinstatement of cocaine and nicotine place preference. Front Pharmacol 4:96. CrossRef Medline

Al-Hasani R, McCall JG, Foshage A.M., Bruchas MR (2013b) Locus coeruleus kappa-opioid receptors modulate reinstatement of cocaine place preference through a noradrenergic mechanism. Neuropsychopharmacology 38:2484-2497. CrossRef Medline

Al-Hasani R, McCall JG, Shin G, Gomez A.M., Schmitz GP, Bernardi JM, Pyo CO, Park SI, Marcinkiewcz CM, Crowley NA, Krashes MJ, Lowell BB, Kash TL, Rogers JA, Bruchas MR (2015) Distinct subpopulations of nucleus accumbens dynorphin neurons drive aversion and reward. Neuron 87:1063-1077. CrossRef Medline

Astur RS, Palmisano AN, Carew AW, Deaton BE, Kuhney FS, Niezrecki RN, Hudd EC, Mendicino KL, Ritter CJ (2016) Conditioned place preferences in humans using secondary reinforcers. Behav Brain Res 297:15-19. CrossRef Medline

Banna KM, Back SE, Do P, See RE (2010) Yohimbine stress potentiates conditioned cue-induced reinstatement of heroin-seeking in rats. Behav Brain Res 208:144-148. CrossRef Medline

Bashiri H, Rezayof A, Sahebgharani M, Tavangar SM, Zarrindast MR (2016) Modulatory effects of the basolateral amygdala $\alpha 2$-adrenoceptors on nicotine-induced anxiogenic-like behaviours of rats in the elevated plus maze. Neuropharmacology 105:478-486. CrossRef Medline

Brielmaier JM, McDonald CG, Smith RF (2008) Nicotine place preference in a biased conditioned place preference design. Pharmacol Biochem Behav 89:94-100. CrossRef Medline

Britt JP, Benaliouad F, McDevitt RA, Stuber GD, Wise RA, Bonci A (2012) Synaptic and behavioral profile of multiple glutamatergic inputs to the nucleus accumbens. Neuron 76:790-803. CrossRef Medline

Bruchas MR, Yang T, Schreiber S, Defino M, Kwan SC, Li S, Chavkin C (2007) Long-acting kappa opioid antagonists disrupt receptor signaling and produce noncompetitive effects by activating c-Jun N-terminal kinase. J Biol Chem 282:29803-29811. CrossRef Medline

Bruchas MR, Land BB, Lemos JC, Chavkin C (2009) CRF1-R activation of the dynorphin/kappa opioid system in the mouse basolateral amygdala mediates anxiety-like behavior. PLoS One 4:e8528. CrossRef Medline

Bruchas MR, Schindler AG, Shankar H, Messinger DI, Miyatake M, Land BB, Lemos JC, Hagan CE, Neumaier JF, Quintana A, Palmiter RD, Chavkin C (2011) Selective $\mathrm{p} 38 \alpha$ MAPK deletion in serotonergic neurons produces stress resilience in models of depression and addiction. Neuron 71: 498-511. CrossRef Medline

Buczek Y, Lê AD, Wang A, Stewart J, Shaham Y (1999) Stress reinstates nicotine seeking but not sucrose solution seeking in rats. Psychopharmacology (Berl) 144:183-188. CrossRef Medline

Buffalari DM, Grace AA (2009) Anxiogenic modulation of spontaneous and evoked neuronal activity in the basolateral amygdala. Neuroscience 163 : 1069-1077. CrossRef Medline

Chen YW, Fiscella KA, Bacharach SZ, Tanda G, Shaham Y, Calu DJ (2015) Effect of yohimbine on reinstatement of operant responding in rats is dependent on cue contingency but not food reward history: yohimbine and reward history. Addict Biol 20:690-700. CrossRef Medline

Crowley NA, Bloodgood DW, Hardaway JA, Kendra A.M., McCall JG, AlHasani R, McCall NM, Yu W, Schools ZL, Krashes MJ, Lowell BB, Whistler JL, Bruchas MR, Kash TL (2016) Dynorphin controls the gain of an amygdalar anxiety circuit. Cell Rep 14:2774-2783. CrossRef Medline

Droungas A, Ehrman RN, Childress AR, O'Brien CP (1995) Effect of smoking cues and cigarette availability on craving and smoking behavior. Addict Behav 20:657-673. CrossRef Medline

Grabus SD, Martin BR, Brown SE, Damaj MI (2006) Nicotine place preference in the mouse: influences of prior handling, dose and strain and attenuation by nicotinic receptor antagonists. Psychopharmacology (Berl) 184:456-463. CrossRef Medline

Grella SL, Funk D, Coen K, Li Z, Lê AD (2014) Role of the kappa-opioid receptor system in stress-induced reinstatement of nicotine seeking in rats. Behav Brain Res 265:188-197. CrossRef Medline

Huge V, Rammes G, Beyer A, Zieglgänsberger W, Azad SC (2009) Activation of kappa opioid receptors decreases synaptic transmission and inhibits long-term potentiation in the basolateral amygdala of the mouse. Eur J Pain 13:124-129. CrossRef Medline

Itzhak Y, Martin JL (1999) Effects of cocaine, nicotine, dizocipline and alcohol on mice locomotor activity: cocaine-alcohol cross-sensitization involves upregulation of striatal dopamine transporter binding sites. Brain Res 818:204-211. CrossRef Medline

Jackson KJ, McLaughlin JP, Carroll FI, Damaj MI (2013) Effects of the kappa opioid receptor antagonist, norbinaltorphimine, on stress and drug-induced reinstatement of nicotine-conditioned place preference in mice. Psychopharmacology (Berl) 226:763-768. CrossRef Medline

Janes AC, Pizzagalli DA, Richardt S, Frederick Bde B, Holmes AJ, Sousa J, Fava M, Evins AE, Kaufman MJ (2010) Neural substrates of attentional bias for smoking-related cues: an fMRI study. Neuropsychopharmacology 35:2339-2345. CrossRef Medline

Kang-Park M, Kieffer BL, Roberts AJ, Siggins GR, Moore SD (2015) Interaction of CRF and kappa opioid systems on GABAergic neurotransmission in the mouse central amygdala. J Pharmacol Exp Ther 355:206-211. CrossRef Medline

Kim JJ, Koo JW, Lee HJ, Han JS (2005) Amygdalar inactivation blocks stress-induced impairments in hippocampal long-term potentiation and spatial memory. J Neurosci 25:1532-1539. CrossRef Medline

Kim T et al. (2013) Injectable, cellular-scale optoelectronics with applications for wireless optogenetics. Science 340:211-216. CrossRef Medline

Knoll AT, Muschamp JW, Sillivan SE, Ferguson D, Dietz DM, Meloni EG, Carroll FI, Nestler EJ, Konradi C, Carlezon WA Jr (2011) Kappa opioid receptor signaling in the basolateral amygdala regulates conditioned fear and anxiety in rats. Biol Psychiatry 70:425-433. CrossRef Medline

Koob GF (2009) Brain stress systems in the amygdala and addiction. Brain Res 1293:61-75. CrossRef Medline

Koob GF (2013) Addiction is a reward deficit and stress surfeit disorder. Front Psychiatry 4:72. CrossRef Medline

Lalanne L, Ayranci G, Kieffer BL, Lutz PE (2014) The kappa opioid receptor: from addiction to depression, and back. Front Psychiatry 5:170. CrossRef Medline

Lalumiere RT (2014) Optogenetic dissection of amygdala functioning. Front Behav Neurosci 8:107. CrossRef Medline 
Land BB, Bruchas MR, Lemos JC, Xu M, Melief EJ, Chavkin C (2008) The dysphoric component of stress is encoded by activation of the dynorphin kappa-opioid system. J Neurosci 28:407-414. CrossRef Medline

Lê AD, Harding S, Juzytsch W, Funk D, Shaham Y (2005) Role of alpha-2 adrenoceptors in stress-induced reinstatement of alcohol seeking and alcohol self-administration in rats. Psychopharmacology (Berl) 179: 366-373. CrossRef Medline

Lerman C, Gu H, Loughead J, Ruparel K, Yang Y, Stein EA (2014) Largescale brain network coupling predicts acute nicotine abstinence effects on craving and cognitive function. JAMA Psychiatry 71:523-530.

Li C, Rainnie DG (2014) Bidirectional regulation of synaptic plasticity in the basolateral amygdala induced by the D1-like family of dopamine receptors and group II metabotropic glutamate receptors: synaptic plasticity in the basolateral amygdala. J Physiol 592:4329-4351. CrossRef Medline

Li C, Pleil KE, Stamatakis A.M., Busan S, Vong L, Lowell BB, Stuber GD, Kash TL (2012) Presynaptic inhibition of gamma-aminobutyric acid release in the bed nucleus of the stria terminalis by kappa opioid receptor signaling. Biol Psychiatry 71:725-732. CrossRef Medline

Madisen L, Zwingman TA, Sunkin SM, Oh SW, Zariwala HA, Gu H, Ng LL, Palmiter RD, Hawrylycz MJ, Jones AR, Lein ES, Zeng H (2010) A robust and high-throughput Cre reporting and characterization system for the whole mouse brain. Nat Neurosci 13:133-140. CrossRef Medline

Mansour A, Khachaturian H, Lewis ME, Akil H, Watson SJ (1988) Anatomy of CNS opioid receptors. Trends Neurosci 11:308-314. CrossRef Medline

Mantsch JR, Weyer A, Vranjkovic O, Beyer CE, Baker DA, Caretta H (2010) Involvement of noradrenergic neurotransmission in the stress- but not cocaine-induced reinstatement of extinguished cocaine-induced conditioned place preference in mice: role for $\beta$-2 adrenergic receptors. Neuropsychopharmacology 35:2165-2178. CrossRef Medline

Mantsch JR, Baker DA, Funk D, Lê AD, Shaham Y (2016) Stress-induced reinstatement of drug seeking: 20 years of progress. Neuropsychopharmacology 41:335-356. CrossRef Medline

Matta SG et al. (2007) Guidelines on nicotine dose selection for in vivo research. Psychopharmacology (Berl) 190:269-319. CrossRef Medline

McCall JG, Al-Hasani R, Siuda ER, Hong DY, Norris AJ, Ford CP, Bruchas MR (2015) CRH engagement of the locus coeruleus noradrenergic system mediates stress-induced anxiety. Neuron 87:605-620. CrossRef Medline

McLaughlin JP, Marton-Popovici M, Chavkin C (2003) Kappa opioid receptor antagonism and prodynorphin gene disruption block stressinduced behavioral responses. J Neurosci 23:5674-5683. Medline

Melief EJ, Miyatake M, Carroll FI, Beguin C, Carlezon WA Jr, Cohen BM, Grimwood S, Mitch CH, Rorick-Kehn L, Chavkin C (2011) Duration of action of a broad range of selective kappa opioid receptor antagonists is positively correlated with c-Jun N-terminal kinase-1 activation. Mol Pharmacol 80:920-929. CrossRef Medline

Minatohara K, Akiyoshi M, Okuno H (2015) Role of immediate-early genes in synaptic plasticity and neuronal ensembles underlying the memory trace. Front Mol Neurosci 8:78. CrossRef Medline

Murray EA (2007) The amygdala, reward and emotion. Trends Cogn Sci 11:489-497. CrossRef Medline

Namburi P, Beyeler A, Yorozu S, Calhoon GG, Halbert SA, Wichmann R, Holden SS, Mertens KL, Anahtar M, Felix-Ortiz AC, Wickersham IR, Gray JM, Tye KM (2015) A circuit mechanism for differentiating positive and negative associations. Nature 520:675-678.

Napier TC, Herrold AA, de Wit H (2013) Using conditioned place preference to identify relapse prevention medications. Neurosci Biobehav Rev 37:2081-2086. CrossRef Medline

Ngolab J, Liu L, Zhao-Shea R, Gao G, Gardner PD, Tapper AR (2015) Functional upregulation of $4^{\star}$ nicotinic acetylcholine receptors in VTA GABAergic neurons increases sensitivity to nicotine reward. J Neurosci 35:8570-8578. CrossRef Medline
Picciotto MR, Mineur YS (2014) Molecules and circuits involved in nicotine addiction: the many faces of smoking. Neuropharmacology 76:545-553. CrossRef Medline

Portugal GS, Al-Hasani R, Fakira AK, Gonzalez-Romero JL, Melyan Z, McCall JG, Bruchas MR, Morón JA (2014) Hippocampal long-term potentiation is disrupted during expression and extinction but is restored after reinstatement of morphine place preference. J Neurosci 34:527-538. CrossRef Medline

Redila VA, Chavkin C (2008) Stress-induced reinstatement of cocaine seeking is mediated by the kappa opioid system. Psychopharmacology (Berl) 200:59-70. CrossRef Medline

Rei D, Mason X, Seo J, Gräff J, Rudenko A, Wang J, Rueda R, Siegert S, Cho S, Canter RG, Mungenast AE, Deisseroth K, Tsai LH (2015) Basolateral amygdala bidirectionally modulates stress-induced hippocampal learning and memory deficits through a p25/Cdk5-dependent pathway. Proc Natl Acad Sci U S A 112:7291-7296. CrossRef Medline

Roth BL (2016) DREADDs for neuroscientists. Neuron 89:683-694. CrossRef Medline

Schindler AG, Li S, Chavkin C (2010) Behavioral stress may increase the rewarding valence of cocaine-associated cues through a dynorphin/ $\kappa$ opioid receptor-mediated mechanism without affecting associative learning or memory retrieval mechanisms. Neuropsychopharmacology 35 : 1932-1942. CrossRef Medline

Sciascia JM, Reese RM, Janak PH, Chaudhri N (2015) Alcohol-seeking triggered by discrete pavlovian cues is invigorated by alcohol contexts and mediated by glutamate signaling in the basolateral amygdala. Neuropsychopharmacology 40:2801-2812. CrossRef Medline

Sinha R, Shaham Y, Heilig M (2011) Translational and reverse translational research on the role of stress in drug craving and relapse. Psychopharmacology (Berl) 218:69-82. CrossRef Medline

Smith JS, Schindler AG, Martinelli E, Gustin RM, Bruchas MR, Chavkin C (2012) Stress-induced activation of the dynorphin/-opioid receptor system in the amygdala potentiates nicotine conditioned place preference. J Neurosci 32:1488-1495. CrossRef Medline

Song M, Wang XY, Zhao M, Wang XY, Zhai HF, Lu L (2007) Role of stress in acquisition of alcohol-conditioned place preference in adolescent and adult mice. Alcohol Clin Exp Res 31:2001-2005. CrossRef Medline

Stefanik MT, Kalivas PW (2013) Optogenetic dissection of basolateral amygdala projections during cue-induced reinstatement of cocaine seeking. Front Behav Neurosci 7:213. CrossRef Medline

Subramaniyan M, Dani JA (2015) Dopaminergic and cholinergic learning mechanisms in nicotine addiction. Ann N Y Acad Sci 1349:46-63.

Titomanlio F, Perfumi M, Mattioli L (2014) Rhodiola rosea L. extract and its active compound salidroside antagonized both induction and reinstatement of nicotine place preference in mice. Psychopharmacology (Berl) 231:2077-2086. CrossRef Medline

Tye KM, Prakash R, Kim SY, Fenno LE, Grosenick L, Zarabi H, Thompson KR, Gradinaru V, Ramakrishnan C, Deisseroth K (2011) Amygdala circuitry mediating reversible and bidirectional control of anxiety. Nature 471:358-362. CrossRef Medline

Van't Veer A, Bechtholt AJ, Onvani S, Potter D, Wang Y, Liu-Chen LY, Schütz G, Chartoff EH, Rudolph U, Cohen BM, Carlezon WA Jr (2013a) Ablation of kappa-opioid receptors from brain dopamine neurons has anxiolytic-like effects and enhances cocaine-induced plasticity. Neuropsychopharmacology 38:1585-1597. CrossRef Medline

Yamada H, Bruijnzeel AW (2011) Stimulation of $\alpha 2$-adrenergic receptors in the central nucleus of the amygdala attenuates stress-induced reinstatement of nicotine seeking in rats. Neuropharmacology 60:303-311. CrossRef Medline

Zhou Y, Leri F (2016) Neuroscience of opiates for addiction medicine: from stress-responsive systems to behavior. Prog Brain Res 223:237-251. CrossRef Medline 